\title{
Public intellectuals: La lutte continue?
}

\author{
John Hartley
}

Curtin University, Western Australia and Cardiff University, Wales

\begin{abstract}
This paper outlines three versions of the intellectual: past, present and future. First, it describes an archetypal 'Parisian' myth; next, the dissolute present or 'public intellectual'; finally, a future vision based on the new concept of 'knowledge clubs'. The paper traces how 'the intellectual' has changed over time, and considers the consequences of hanging on to the past, especially by adding the word 'public' to 'intellectual'. While retaining the appearance of a character long dead, this phantasm may blind contemporary analysis as to the direction in which to look for 'public thought' in the future. It argues that the concept needs to be rethought according the approach of 'cultural science', where knowledge-agency belongs to culture-made groups not individuals.
\end{abstract}

\section{Intellectuals 1: Something in the coffee?}

Within the very limits of the teaching space as given, the need is to work at patiently tracing out a pure form, that of floating (the very form of the signifier); a floating which would not destroy anything but would be content simply to disorientate the Law. The necessities of promotion, professional obligations (which nothing then prevents from being scrupulously fulfilled), imperatives of knowledge, prestige of method, ideological criticism - everything is there, but floating. (Roland Barthes, 1977a)

Roland Barthes had a point when he wrote an essay on 'Writers, Intellectuals, Teachers' (1977a: 190-215), in which he contrasted speech and writing. The teacher, he argued, 'is on the side of speech', while the writer is 'every operator of language on the side of writing'. Between the two is the intellectual, defined by Barthes in his 'neutral' mode (Barthes 2005), as 'the person who prints and publishes his speech' (1977a: 190). Rather a bathetic definition, you may say, but it is part of a paradigmbaffling project to deconstruct the binary oppositions that make discourse meaningful. Accordingly, Barthes is not content to accept such binaries, and in the ambiguous non-place between speech and writing he inserts the intellectual. He connects 'the intellectual' not with ideas but with speech, and speech with teaching. Barthes had a 
lot to say about speech, including a structuralist concern for the extent to which 'language speaks us', as they used to say, as well as poststructuralist pleasure in disrupting the doxa or 'Law' of language - a task he gave not in the first place to intellectuals, but principally to writing (of the 'writerly' kind that could produce jouissance). So here is a three-part distinction of terms that plays almost no part in current (21st-century) discussions of the topic: the typology of Writer, Teacher, Intellectual.

These days, in discussions of the role of the intellectual, the 'teacher' is almost forgotten, perhaps in line with the reduction of status of teachers in many universities to an abject figure of the proletarianised precariat. But Barthes reckoned that 'between the language of the teacher and that of the intellectual there is hardly any incompatibility (they often co-exist in a single individual)'. Over against the speakerteacher-intellectual he saw the writer as the one who 'stands apart, separate': 'Writing begins at a point where speech becomes impossible' (Barthes 1977a: 190). He was quick to gloss 'impossible' as 'a word that can be understood in the sense it has when applied to a child'.

But before we get to writing, it is instructive to consider more closely the context in which Barthes can claim that teacher and intellectual are coeval, with 'hardly any incompatibility'. Despite the vigour of other national intelligentsias in the 60s, the 'preferred reading' of 'the intellectual' was that of Parisian cosmopolitan café-society, and Barthes was one of its archetypes. In the 1970s, Anglophone cultural studies became highly Francophile: structuralism, semiotics, deconstruction, psychoanalysis and even Marxism were read with a French accent. Paris had the 1960s - 'years of hope, days of rage', as Todd Gitlin put it (1987) - written all over it. Here was a heady combination of Jean-Luc Godard's À Bout de Souffle, 'Continental' philosophy, Les Événements of '68, where you might bump into Althusser (or his shrink Lacan) in the cafe, ${ }^{1}$ or catch the bus over to the revolutionary Paris University VIII to see Judith Miller, Lacan's daughter (until she was fired for handing out course credits to someone she met on a bus, as an anti-capitalist gesture), or else to see head-ofdepartment Michel Foucault, when he wasn't busy joining in a student occupation and

\footnotetext{
${ }^{1}$ As here, perhaps? - https://chaiselonguetheorists.wordpress.com/2013/12/04/exam-one-post$\underline{\text { marxism-21. }}$
} 
throwing projectiles at the police. Or, you might attend one of Foucault's weekly lectures at the Collège de France, which Barthes himself joined in 1977, having been nominated by Foucault (Barthes 2005) and where, just outside, he was run down by a laundry van (cleaned up by the binary-loving bourgeoisie?) while walking back from Sunday lunch with soon-to-be President François Mitterand in 1980. In the Parisian air, there's the whiff of insurrection as well as Gitanes. In the coffee crema, there's philosophy - literally, in the case of Godard's 1967 film 2 ou 3 choses que je sais d'elle/Two or Three Things I Know About Her (Ford 2013).
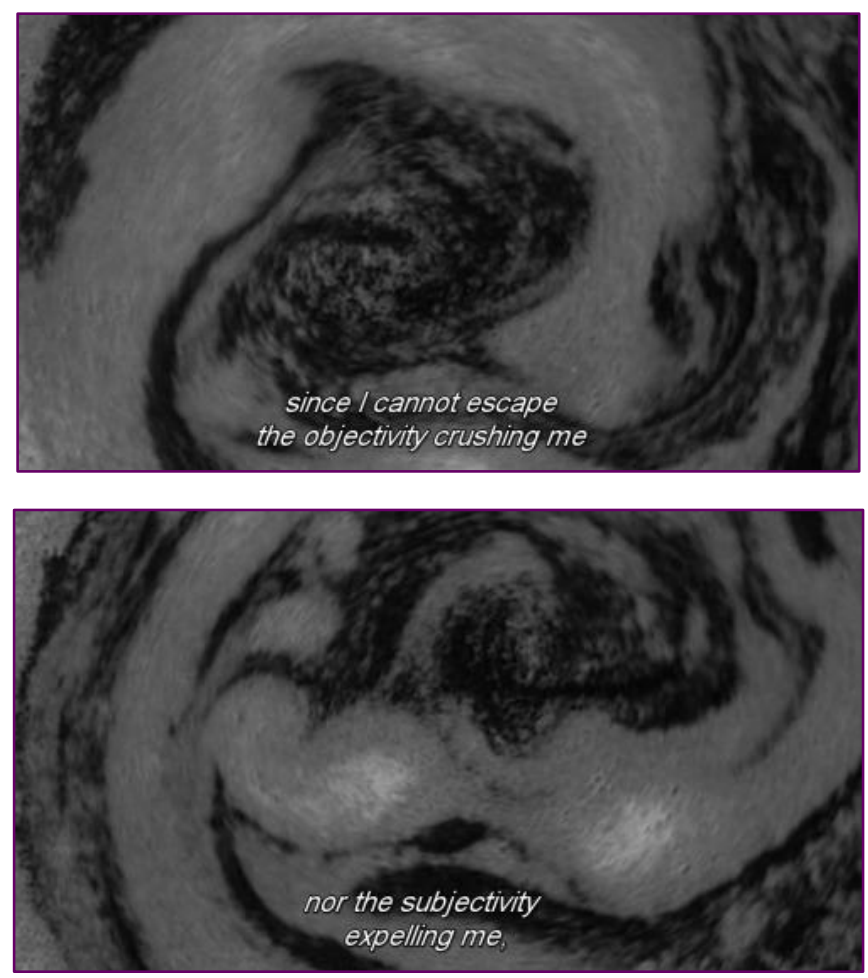

Coffee philosophy: Screen grabs of 2 ou 3 choses que je sais d'elle by J-L Godard

In such a climate, the link that Barthes makes between teachers and intellectuals is much easier to 'read', as it were. Intellectuals were hot. Foucault's Collège de France lectures were packed out, as much a part of pop culture as intellectual, not least because of the Collège's rule that such events should be free and open to the public. This kind of teaching, you might say, was not outsourced, low-value drudgery, but part of the avant-garde entertainment complex, a 'mass' medium in its own right. You spoke, you published; you were teacher, intellectual ... entertainer, celebrity ... militant, hero ... film-star, philosopher ... it was all the same, as modelled by an amazing roll call of French teacher-intellectuals whose names still resonate (Lucy 
2016). So when the Youth of The Day crowded into the lecture hall from the demo or the café, to critique the present, to capture the future, to make love and life, in pursuit of what Barthes calls 'an art of living, the greatest of all the arts' (1977a: 215), Barthes was talking directly to them.

Despite the sectarianism that makes and mars progressive politics, and which had riven the intellectual Left after 1968 in France as elsewhere, Barthes could still claim in 1977 that 'One of the things that can be expected from a regular meeting together of speakers is quite simply goodwill' (1977a: 213). What optimism! What ambition! Goodwill among the many different parties, causes - and intellectuals - of 'the' Left was never secure. In this period, Left politics was gradually transforming from classbased vanguardism and militancy, agitated by parties well to the left of parliamentary socialism, towards issues-led 'new social movements', aiming (for instance) at liberating subjectivities, opposing patriarchy, colonialism, racism etc., demonstrating for (anti-nuclear) peace, environmental and social causes, or seeking new forms of personal enlightenment through sex, drugs, rock'n'roll and Eastern mysticism. Each of these movements and issues threw up its own intellectuals, few of whom were based in universities or even political parties: some were gurus, some pop stars or film stars, others were writers. Leadership in new ideas was passing from politically constituted parties to the market: radicalisation was more likely to follow from hearing John Lennon than John Maclean. ${ }^{2}$

At this time, in Germany (Red Army Faction), Italy (Red Brigades), Britain (IRA and others), ${ }^{3}$ and Spain (ETA), political militancy spilled over into terrorism. Some intellectuals sympathised, holding fast to the Bolshevik notion of party-and-class as the agent of change, without renouncing violence. Most controversial among these, perhaps, was the Italian philosopher Antonio Negri, who served a substantial term of imprisonment on charges of terrorism (later downgraded). Negri is still regarded with

\footnotetext{
2 John Maclean was a schoolteacher and Marxist hero of 'Red Clydeside'. His fame lasted into the 1970s via popular music: Dick Gaughan's rendering of Hamish Henderson's 'Ballad of John Maclean' (1972), celebrating MacLean's release from prison in 1918 after anti-war agitation and refusing conscription: www.dickgaughan.co.uk/songs/texts/johnmacl.html.

${ }^{3}$ For instance, the Free Wales Army (active - and convicted - in 1969). See:

www.walesonline.co.uk/news/wales-news/images-spark-interest-forgotten-free-2087129.
} 
deep suspicion by some commentators. ${ }^{4}$ He retained a commitment to party-led class politics. But as Timothy Murphy, editor of his revolutionary writings (Negri 2005) has shown, Negri's conceptualisation of what the party comprised changed with the times, from (i) a Leninist, command-and-control vanguard elite, centred on the proletariat (male factory workers); to (ii) a middle position where it was seen as what he called a 'party of mass vanguards', being the 'totalization of mass initiatives and workers' leadership', i.e., the workers not the party called the shots in deciding what struggles to pursue; and finally to (iii) the party as 'an external and subordinate tactical appendage of the class', i.e. an action-squad with no control over proletarian 'self-valorization' (Murphy 2005: x). In other words, to keep hold of an idea of the party at all, Negri has to concede, first, that the composition of the class of which it is the party must expand to include 'students, women, the unemployed, prisoners, and other subordinated groups', i.e. it has to co-opt the new social movements that it had played no role in engendering. Second, it slowly dawns on Negri that these folk can think and speak autonomously for themselves. As Murphy puts it, what links his writings over the period is 'Negri's gradual recognition of the self-sufficiency of the proletarian masses themselves: their ability to conceptualize, produce, and organize their own forms of struggle without the need for external command of any kind' (2005: x). What need of a Party at all?

In 1983, Negri fled to France from Italy, gaining sanctuary - and a new audience - at Paris University VIII and at Derrida's Collège International de Philosophie. Was he still, but now in the guise of an international intellectual celebrity and teacher, the 'cattivo maestro' - bad teacher/evil genius and corrupter of youth, as his prosecutors alleged (Murphy 2005: xvi)? He certainly sounded like it: 'every act of destruction and sabotage redounds upon me as a sign of class fellowship ... nor does the suffering of the adversary affect me' (Negri 2005: 259).

\footnotetext{
${ }^{4}$ See for instance the exchange between Negri and Alexander Stille in New York Review of Books: http://www.nybooks.com/articles/archives/2003/feb/27/apocalypse-soon-an-exchange/, following a review by Stille in which he had written: 'In his homeland, Negri is the most notorious of what the Italians call $i$ cattivi maestri, the bad professors who poisoned the minds of a generation, sending tens of thousands of young people to the barricades to destroy themselves for a Communist revolution that could never happen': www.nybooks.com/articles/archives/2002/nov/07/apocalypse-soon/.
} 
Is this the point 'where speech becomes impossible', in Barthes's sense? Is Negri, with his fantasy of 'fellowship' in 'destruction and sabotage' (rather than Barthes's 'goodwill' among speakers), one of those teachers who encourages the class to be as unruly as possible, or is he himself merely the naughty child of speech and teaching? Where does the 'speech-teaching-intellectual' combination go from here? For Barthes's distinction between speech and writing, the answer is clear: the intellectual must go across to the 'separate' domain of writing. That is exactly what happened to Negri. As Verso's blurb for Books for Burning puts it, his texts of the 1970s 'were later misread and misrepresented by the Italian state in its attempt to frame Negri as responsible for the assassination of former Italian president Aldo Moro, as the leader of the Red Brigades, and as the mastermind of an armed insurrection against the state'. His defence against these charges of terrorism was, of course, to argue that his writings belonged to an autonomous domain of ideas and were not an incitement to literal violence.

The professional intellectual retreated from both class and classroom action, to take refuge in textuality and metaphor (not violence but 'violence'). But the cat was out of the bag. As Gramsci (1971) had known, everyone is an intellectual because everyone can think. Now, with 'the personal as political' and activism dispersed across the social domain, up to and including the global markets in entertainment (especially music), there was no place left for professional revolutionaries (or philosophers) any more than for 'traditional' or 'universal' intellectuals (Foucault 1977).

Now, 'the' intellectual was dispersed among myriad causes with no central leadership, 'organic' in a way that even Gramsci (1971: 9) may not have wanted to concede, because the principle of organisation, a party function, was deleted. The command and control of ideas passed from professional elites to the market (which of course had always dealt in them, out of the sight of intellectuals perhaps), and henceforth were self-organising, which also meant that they were subject to trends, crazes, marketing, branding, investment, the vagaries of consumer taste and manipulation by vested interests. But still, ideas could spring from anywhere, and gain adherents from anyone. 'The intellectual' could not operate without mediation,

\footnotetext{
${ }^{5}$ See: www.versobooks.com/books/24-books-for-burning.
} 
and the 'mass media' were by now an ascendant force in society, with their own rules and routines. The system of mass media (public and commercial entertainment and information across print, broadcast, cinema, music media) was the only one capable of coordinating such complex interactions, and so the claim that intellectuals could hold themselves apart as outsiders or exiles (except in Barthes' sense, as writers) was more than ever untenable. The intellectual function was marketised, mediatised and democratised.

It follows that intellectual and pop culture could no longer be separated, in practice or theory. Again, this was not new, for even in the days of Vietnam and revulsion against imperial 'Amerika' (as its own Yippies called it), the canniest European intellectuals and artists - Godard, say, or Nabokov, or Eco - were fascinated by American popular culture, the movies, the music, the cars, even as they used the sign of America to signal the end of everything their own cultures had held dear. Godard's 2 ou 3 choses had set the theme in train, back in 1967 (Ford 2013). Among plenty of other examples, a memorable emblem of this mode of (non-binary) thinking is Jacques Tati's canny film Trafic (1971), where America is the source of both soaring hope and crushing reality. ${ }^{6}$ It sends up car culture while frankly acknowledging the Americanness (and TV-mediation) of the next quantum leap in human mobility that is already upon it, in the shape of the 1969 moon landings. Bumbling Monsieur Hulot (for it is he, in his camper van) meets 'giant leap' Neil Armstrong or, at least, coexists with him. One monopolises every TV set in the car-clogged city, while the other is stuck in traffic, destined neither to reach his destination nor to lose his faith in gadgetry.

\footnotetext{
${ }^{6}$ Note that the title of Trafic is an Americanism, for the French for 'traffic' is 'circulation'.
} 


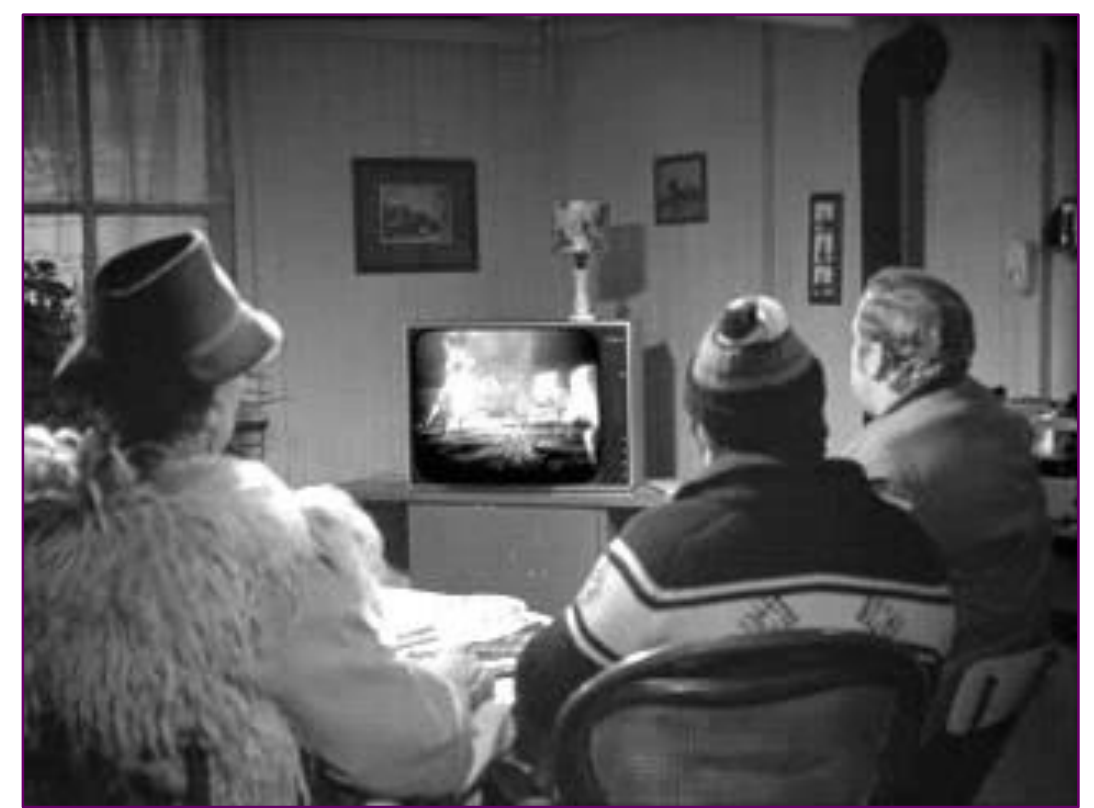

Monsieur Hulot watches the moon-landings: screen grab of Trafic, by Jacques Tati (www.orbit.zkm.del?q=node/378)

So let us leave that apparition, the Parisian intellectual, lost in suburban space, in the company of the harbinger of another kind of modernity, M. Hulot. What to do, but to join the global audience, sit back in wonder, and watch?

\section{Intellectuals 2: 'A fellow of doubtful nature'?}

I define the Neutral as that which outplays the paradigm, or rather I call Neutral everything that baffles the paradigm. For I am not trying to define a word; I am trying to name a thing. The paradigm, what is that? It's the opposition of two virtual terms from which, in speaking, I actualize one to produce meaning. (Roland Barthes 2005: 12-13)

The charisma of Paris in the 1960s and 70s remains strong - as does that of America too, when it comes to that. But as I've argued, this was just the moment when 'the' intellectual had dissolved into popular culture, the market, and the media; and when political leadership was devolving away from parties and towards autonomous groups and networks. Among those most sceptical about the function of the intellectual as outsider, or bande à part (as Godard might have put it), were these very intellectuals, Barthes (and Foucault) prominent among them. In his inaugural lecture at the Collège 
de France, Roland Barthes dubbed himself 'a fellow of doubtful nature'. He felt his every 'attribute' was 'challenged by its opposite'. But of course this doubtfulness was strategic as well as autobiographical. Chief among the opposites Barthes wanted to challenge was the one he discerned between the freedom of speech (and of teaching at the Collège) and the power of structure, which he attributed ultimately to language itself:

We discover then that power is present in the most delicate mechanisms of social exchange: not only in the State, in classes, in groups, but even in fashion, public opinion, entertainment, sports, news, family and private relations, and even in the liberating impulses which attempt to counteract it. I call the discourse of power any discourse which engenders blame, hence guilt, in its recipient. Some expect of us as intellectuals that we take action on every occasion against Power, but our true battle is elsewhere, it is it is against powers in the plural, and this is no easy combat (Barthes 1977b).

Already we have entered the present: a world characterised by the issue-editors of this journal in their call for papers about the 'public intellectual'. For Barthes, media, networks and celebrity are already hard at work, often in the name of those 'liberating impulses'. But the duty of 'us as intellectuals' is not, as the phrase now has it, to 'speak truth to power'. Barthes knows there's no doing that, for speech is co-present with power, and he chooses to do battle with language itself: 'To speak, and, with even greater reason, to utter a discourse is not, as is too often repeated, to communicate; it is to subjugate' (Barthes 1977b). Nevertheless, Barthes presses on with his investigations, albeit in the pre-scientific form of essays - that 'ambiguous genre in which analysis vies with writing' - knowing that intellectuals are not exempt from the powers they contest. He sees the 'true battle' for intellectuals here, in combatting powers that they themselves cannot avoid. This is the moment of the 'impossible' child: the moment when 'analysis' gives way to 'writing'. 


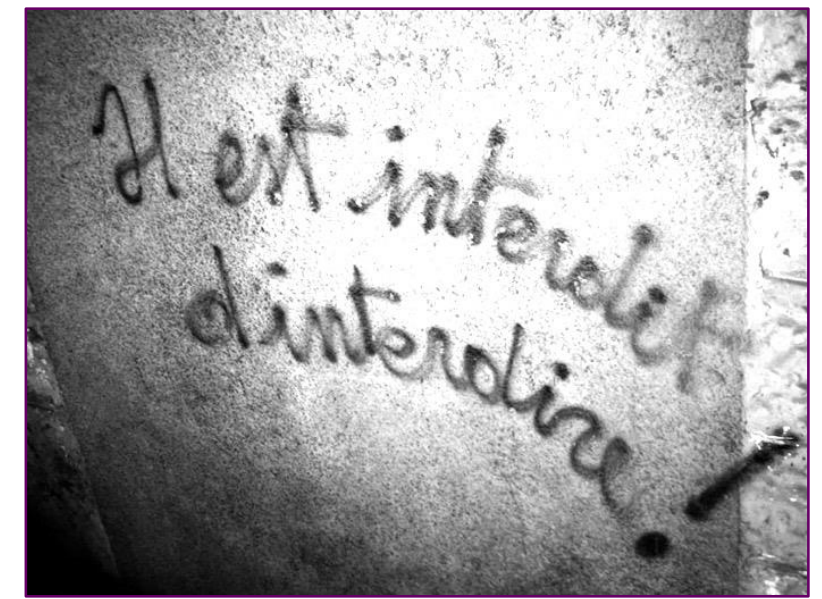

Politics trumps philosophy: May 1968 slogan, Paris. 'It is forbidden to forbid!'7

How is that combat faring today? Coming up to date, it is instructive to note the language changing as we speak. The talk is not of 'the' intellectual, but of the 'public' intellectual. Barthes's original tripartite distinction between speaker/teacher, intellectual and writer has transformed into one between academic, mediator, and celebrity. Celebrity becomes a goal - and a profession (e.g. Richard Dawkins). ${ }^{8}$

Barthes designated writing as a separate domain. For him it was perhaps the only place (in discourse) where, recognising that power cannot be evaded, he could nevertheless evade it: 'the only remaining alternative is, if I may say so, to cheat with speech, to cheat speech' (Barthes 1977b); to cheat it with writing, which Barthes is bold enough to call both a 'grand imposture' and 'literature':

This salutary trickery, this evasion, this grand imposture which allows us to understand speech outside the bounds of power, in the splendour of a permanent revolution of language, I for one call literature. (Barthes 1977b)

Barthes turns the writer into a latter-day Trickster (Hartley 2010). This cheating imposter is the one who can survive within writing, which itself, as literature, keeps language unfixed: here's how you can 'disorientate the Law' (Barthes 1977a). This is

\footnotetext{
${ }^{7}$ Source: 'Situationist' by Espencat - Own work. Licensed under Public Domain via Wikimedia Commons: http://commons.wikimedia.org/wiki/File:Situationist.jpg\#/media/File:Situationist.jpg. ${ }^{8}$ See: www.theguardian.com/science/2015/jun/09/is-richard-dawkins-destroying-his-reputation.
} 
the 'literary' intellectual, as opposed to the 'public' one who opposes power by using 'a discourse which engenders blame, hence guilt' to achieve celebrity.

Perhaps the problem lies in the word public. It changes the intellectual into something else: a fame-seeking, media-savvy academic. As a modifier of other terms, 'public' can signify public functions where private ones might also be expected: for example, access to a place (public house, public bar, public toilets); or it can signify a public office (public hangman). A pair of Google Ngrams shows the frequency of various versions of the modifier 'public'. The first runs from the 1980s to 2007, in books in English. Most frequent in this sample is 'public house', followed by 'public speech', with 'public intellectual' rising from nothing (about 1990) to third place, overtaking 'public toilet' and 'public bar' along the way. This shows that the 'public intellectual' is a recent coinage, trending upwards but still playing second fiddle to the pub, at least in published discourse. The second Ngram, at greater scale and over a much longer timeframe, runs from 1800 to 2000, shows how 'public domain' overtakes 'public house' in the nineteenth century, while the much more recent 'public sphere' (which has replaced the older and more neutral 'public affairs' - not shown here), far outstrips 'public intellectual'.

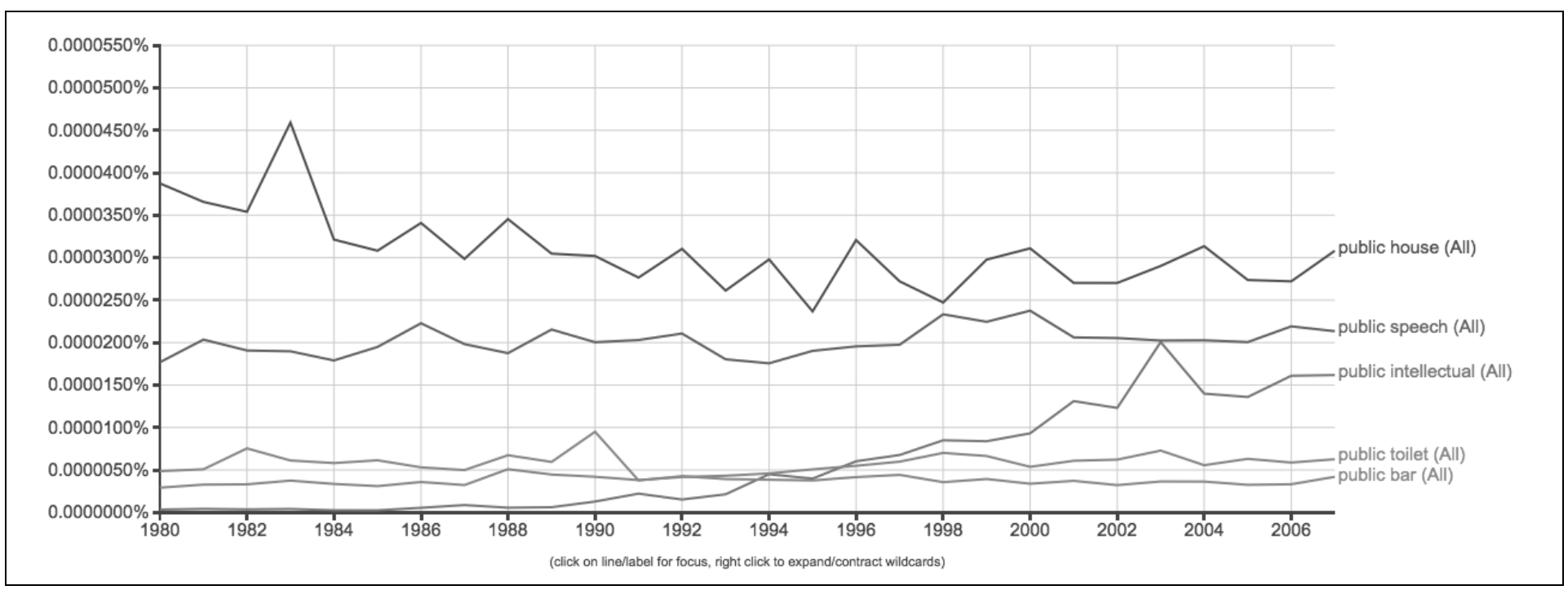

Ngram 1 showing the terms public house, public speech, public intellectual, public toilet, public bar, in books in English 1980-2007. 


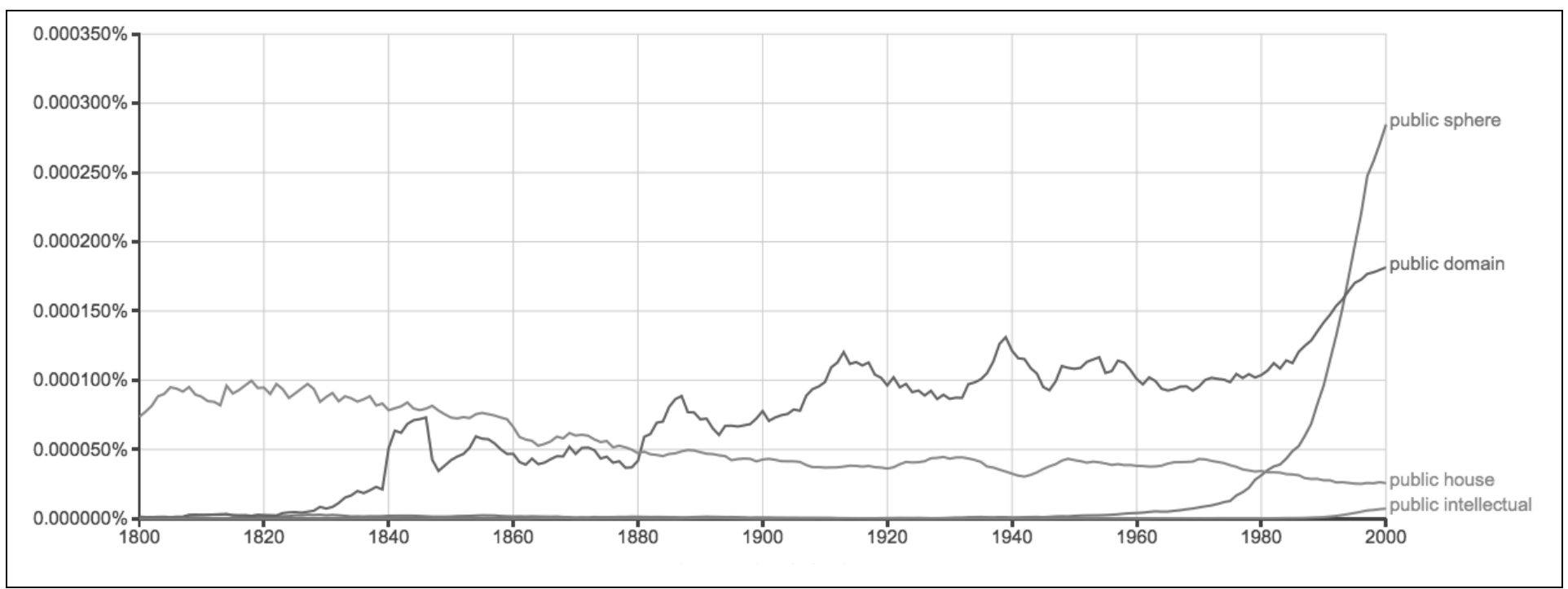

Ngram 2 showing the terms public sphere, public domain, public house, public intellectual, in books in English $1800-2000$

How might one explain the recent growth of the term 'public intellectual' and 'public sphere'? Their appearance in the wake of Reagan-Thatcherism is doubtless significant, at a time when deregulation, privatisation and neoliberalism were ascendant in the Western political sphere, both in policy and in rhetorical politics, provoking an opposing reaction among the defenders of public culture and institutions, from public housing, education and welfare to public service broadcasting and public culture. Since then, the term 'public' has become adversarial, a marker of left/right allegiances. Because this is politics, 'our' side of the opposition is treated as universal and self-evident, while 'theirs' is duplicitous and dangerous: in short, the knowledge involved is tribal - or 'demic', belonging to culture-made groups (Hartley \& Potts 2014).

At once, the 'public' intellectual is caught up in opposition of exactly the kind that Barthes refused. If you're 'public' then you're an opponent of 'private' - the private sector, private enterprise, privatisation. Binary opposition speaks through the 'public' intellectual, whatever they may say. So much so that $a$ 'public good' (a neutral term from economics for 'non-rivalrous' and 'non-excludable' goods) becomes the public good (a moral economy). A structurally oppositional stance is presented as universally binding, as if the public sector is preferable to the private in all circumstances. 


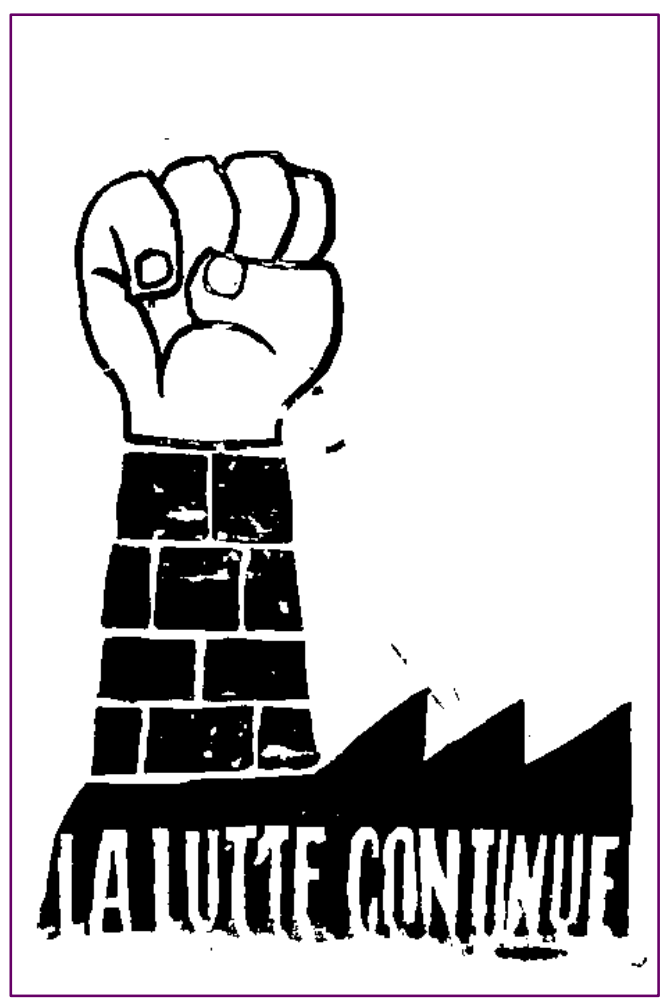

La lutte continue (The Struggle Continues), May1968. Atelier Ecole des Beaux-arts: (anonymous poster). Source: http://gallica.bnf.fr/ark:/12148/btv1b9018349b. ${ }^{9}$

The ideological adversaries of 'big government' (i.e. opponents of the public sector), including pro-corporate interests in newspapers and media groups as well as ideologues in political parties of the right, encourage and foment public scepticism about the claims of partisan intellectuals, with the results that all can see: publicsector scientific, intellectual and cultural groups and individuals are politicised whether they like it or not, and there's a chasm between what is known (science) and what is enacted (policy). If this is a 'knowledge-driven economy' it's a pretty partial kind of knowledge, and its bearers are defeated by the very value that they espouse.

If the 'public intellectual' is partial, then where is its opposite: the 'private intellectual'? Private enterprise and its apologists simply do not use this discursive register or lexicon. Their terms are 'public opinion', 'public relations' and marketing, i.e. an important sector of the market economy devoted to the communication of

\footnotetext{
${ }^{9}$ The citation attached to this poster in the collection of the Musée Carnavalet - Histoire de Paris makes clear the direct line of filiation from revolutionary, political design to subsequent market leadership in the art of publicity: These posters showed a 'graphic inventiveness ... which, paradoxically, then permanently influenced the world of advertising [la publicité]'. www.carnavalet.paris.fr/fr/collections/la-lutte-continue.
} 
ideas. Here a 'private' intellectual might range from ideological warriors - Bjørn Lomborg being a current example - to advertising gurus. 'Brand ambassadors' include the many celebrities who make their name in one sphere (the performing arts) and then rent their fame for product promotion or partisan endorsements, some of them for public institutions or causes. While such figures are familiar enough, they are not often thought of as 'intellectuals', private or otherwise, despite what we know about their importance in the circulation of new ideas. Whether such figures are thought of as cattivi maestri, evil geniuses and corruptors of youth (e.g. Silvio Berlusconi and other politically active media moguls), or as figures of hope and identification with good causes (e.g. Dame Angelina Jolie, DCMG), ${ }^{10}$ they don't call themselves intellectuals - and neither do academics, who are more likely to denounce them than to welcome them as fellows. This may be a strategic mistake if you're trying to understand the function of intellectuals in society.

But in fact there's not much discussion about what a 'private intellectual' might be, even among those who are interested in 'public' ones. Sometimes the term is applied to the scholar whose knowledge is produced for a specialist peer group only, circulated in publications that the public never see, and who plays no part in public affairs or public life. That figure, once again, is the negative polar opposite of the public intellectual. Such a view motivates one of the most important developments in scholarly communication of recent times, the drive towards Open Access, where knowledge is made public using the capabilities of digital archives and internet connectivity. The argument goes that most research is produced by scholars employed in public institutions using public funds, but published in privately owned journals that these institutions then buy back at great cost to the taxpayer. Surely such knowledge ought to be a 'public good' too? Here, we do begin to see a shift from the intellectual as moral warrior to a system-based interest in the public state of knowledge. Unfortunately, the idea that all scholars are - or should become - public intellectuals is not practical in the current adversarial climate. To be able to imagine such an extension of the intellectual function we need to rethink the whole set-up.

\section{Intellectuals 3: Clubs and commons?}

\footnotetext{
${ }^{10}$ See: http://en.wikipedia.org/wiki/Order_of_St_Michael_and_St_George.
} 
For though my career has been academic, I am without the usual qualifications for entrance into that career. And though it is true that I long wished to inscribe my work within the field of science -literary, lexicological, and sociological - I must admit that I have produced only essays, an ambiguous genre in which analysis vies with writing. (Roland Barthes, 1977b)

Roland Barthes was on to something when he sought to 'baffle the paradigm', where meaning is made by opposing 'two virtual terms from which, in speaking, I actualize one to produce meaning' (2005: 12). This is the problem with 'public' - it cannot be uttered without 'meaning' opposition. It doesn't specify what an intellectual is or does, but recruits intellectuals to a cause of faith (troth) rather than that of making knowledge (truth). However, while refusing to be conscripted into the action brigade of those who are 'against Power', Barthes was still making a distinction between two kinds of intellectual, the fighting one and the literary one. Despite his own doughty struggles against bourgeois thought, going back to the 1950s, he clearly preferred, and indeed was, the latter, even though he 'desires the Neutral' (2005: 12).

But that doesn't help us to find what 'outplays' (the word he uses is 'déjoue': outsmarts, thwarts, foils, outwits) the oppositional paradigm. Perhaps the problem lies in the word intellectual. Whether public or private, literary or militant, Paris or publicity, the problem is that it refers to a person, an individual, and therefore to a character, subject, identity, persona etc., which doesn't necessarily help us to analyse the production and distribution of critical and literate thinking in the digital age, for which we may need to get away from 'intellectuals' altogether, so long as they persist as ghosts in the machine, posing as humans. Only then can we move towards what Barthes wanted for his analytical work: to 'inscribe' it 'within the field of science' (1977b).

Clues, directing us to the path we should have been taking to get there, can be retrieved from the preceding sections of this (pre-scientific) essay. First, we need to abandon humanist individualism. Second, we need to abandon the 
public/private (or any other) opposition. And third, we need to get out of Paris. Instead of using 'intellectuals' at all, my own preferred term is 'public thought' (Hartley 2012: chapter 4). ${ }^{11}$ The reason is that thought is produced, exchanged and diffused in systems, where the concept of speaker, writer, teacher, intellectual, even 'person' as the cause, originator or author of ideas is barely relevant. As soon as we turn to the global internet and digital media, we find that public thought has escaped confinement to the human individual. Furthermore, the internet is not structured in oppositions, nor does it respect previous hierarchies of prestige or authority. Public thought can come from anywhere, originated by anyone. Some ideas come from celebrities at the head of the Andersonian long tail, but myriad more are made at the tail, any of which (and according to the mathematics of probability, not the politics of opposition and exclusion) can trade places with the head and become celebrated.

So far, so good. We've left the public/private opposition behind, for the internet is made of private (proprietary) platforms in which expression of thought is public (albeit constrained by and generative of new political differences based on digital divides, IP rights, privacy/surveillance and the like). We've left Paris behind (although, because it is 'liked' by so many, its traces are all over the internet, which is always just a few clicks away from nostalgia). We've left the 'metaphysics of presence' behind too, for agency here is systemic and distributed, such that 'thought' is no longer a function of persons but a humanmachine hybrid, readily detached from one 'owner' or context and transferred to myriad others, where its productivity may be greater but unpredicted by the originator. And we've put in place instead a model of a large array of complex systems, in which scale and dynamism, regularities and turbulence, clash and conflict as well as collaboration and cooperation, demand a mode of analysis unlike that of literate critique by individual intellectuals, and more akin to the science of meteorology, i.e. probability, where forecasts rather than linear predictions are possible, using immense numbers of data-points and constantly modified computational models.

\footnotetext{
${ }^{11}$ I borrow the term 'public thought' from Clay Shirky, in his answer to The Edge's annual question for 2010: 'How is the internet changing the way you think?' Shirky discussed what he calls 'the shock of inclusion'. See: https://edge.org/response-detail/11609.
} 
But we're not there yet, for the internet is not a uniform space. In other words, it's not an open 'public sphere', where public thought can be universally created and accessed; or where new ideas enlighten the system from one end to the other without let or hindrance. This means, while we're on the subject, that calls for Open Access of knowledge, welcome as they are, only go so far, because this model is still operating the private/public binary. Its proponents want scholarly knowledge to come out from behind publishers' IP, DRM, paywalls and other mechanisms for creating artificial scarcity, that is, to be converted from private goods to public goods, available to all. But market forces still apply, and 'private' intellectual work does not enter a smooth 'public' universe but one that is already lumpy. ${ }^{12}$ Incumbent players seek to maintain their position by capturing public thought as it shifts from analogue to digital mode. Clumps include former news-media mastheads (Guardian for thought; Daily Mail for celebrities); born-digital sites devoted to creating an 'invisible college' among the digerati (The Edge); and hybrid forms like TED Talks and airport bestsellers. As has been widely noted, professional expertise gives way to crowd-sourced, socially networked production and distribution of ideas. The logic of the system shifts from the authority of the author to the spreadability of the idea and its uptake among users (Jenkins et al., 2013).

Attention becomes its own measure: you're a thought leader if sufficient participants 'follow', 'like' or 'comment' on your ideas; if not, not. Thought that is sufficiently liked might end up in a YouTube or FB 'university'; ideas that are well distributed (Wikipedia) may trump disciplinary knowledge. Folksonomies outwit taxonomies; self-organising groups regulate knowledge practices online. Everyone can play (and so 'outplay' the paradigm), from celebrity Tweeters to anonymous originators of new 'memes' that flash across the world from anywhere in the system. Innovation may be most intensive not in metropolitan centres like Paris but at the margins, in neglected or isolated regions along contested borders, among unfavoured populations, or in the clash of difference among groups.

\footnotetext{
${ }^{12}$ For the 'lumpy universe', see: http://imagine.gsfc.nasa.gov/science/questions/lumpy.html.
} 
Such phenomena are widely noticed and have begun to be understood in descriptive detail, but much of the critical attention that is devoted to them is still organised around the public/private binary, including this special issue of MIA. A way out of that impasse, however, may be to hand. A group of researchers working in what we are calling 'cultural science' (Hartley \& Potts 2104) is investigating new models of publishing, Open Access scholarly knowledge, and the sociocultural economics of the growth of knowledge. As well as Jason Potts (RMIT), they include Lucy Montgomery and myself at Curtin, Ellie Rennie at Swinburne, and Cameron Neylon, until recently of PLOS, among others.

Instead of continuing with the distinction between public and private goods, we have begun to organise our approach around 'club' goods (Buchanan 1965) and 'common goods' (Ostrom 1990; Ostrom \& Hess 2007). This is not the place for a detailed exposition of a nascent research program, but we think it points to a much more robust model of how innovations and 'newness' - new ideas - are produced, and how they are distributed and taken up in the overall process of knowledge-growth, which itself underlies economic growth and cultural improvement alike. We are developing the concepts of 'knowledge clubs' and 'knowledge commons', deriving them from our attempt to identify a cultural science based on naturalistic, evolutionary and complexity principles, to arrive at a new understanding of communication and culture. This is probably not quite the science that Barthes dreamed of, but that's really the point: in the 1970s the evolutionary and complexity sciences were not where they are now, and the effort to link critical humanities with them was hampered by opposition to evolutionary theory ('social Darwinism').

While the sciences have made amazing progress since the 1970s, in the humanities we're still reading essays from Paris. If we are to understand how ideas are made, by what kinds of agency, and how they are distributed across whole populations to effect changes at system level, then we're going to have to have another go at science. This is not just a matter of gaining the numeracy to be able to deal with the big data generated by the internet, social networks and digital media. More important is the problem of how to establish and trace causal sequence in such a complex and variable object of study as knowledge, and of how to constitute a field where new work adds 
to what has been achieved in a systematic way, rather than vying for adherents based on ideological affiliation.

How, in short, can we achieve 'Neutral' status for intellectual inquiry about public thought itself? Hartley and Potts (2014) attempt a first-approximation answer to that question by linking culture with the economics of discovery and innovation, seeking to understand the role that culture plays in the growth of knowledge. The conclusion we come to is that culture makes groups; groups make knowledge; and the way in which knowledge is constituted bears all the traces of that process across the span of human history. However, successive adoptions of new communications technologies - speech, writing, print, electronic and internet - have enabled quantum leaps in the growth of knowledge, generating successive economic epochs: hunter-gatherer, agricultural, industrial, information and creative.

All along, groups are the key to both culture and knowledge. Cooperative and competitive groups of non-kin are our species' unique survival mechanism (Pagel 2012). They are constituted and bound together in language, culture, shared codes, know-how, technology and sociality - fictions, as Harari (2014) calls them, including religion, nation, the law, money, firms. They are differentiated from and hostile to competing groups, a stance that is signalled by incommensurable languages and knowledge systems, such that 'our' knowledge is trusted but 'theirs' isn't. It follows that knowledge, meaningfulness and new ideas (innovation) are the products of groups, which also determine individuality and thus 'personae' (of the kind that David Marshall studies) within their bounds (culture). The fact that individuals these days have access to unprecedented numbers of groups - not only family, languagecommunity and ethno-territorial descent but also groups affiliated by taste, affinity and difference - means that identity itself is due for a rethink. This work is well under way of course: e.g. (among many) Tama Leaver's project on 'the ends of identity'; ${ }^{13}$ Eleanor Sandry's on robots and communication (2015); more widely, the work of Zizi Papacharissi, Nancy Baym, Alice Marwick, Kate Crawford and others (Hartley, Burgess \& Bruns 2013).

\footnotetext{
${ }^{13}$ See: www.tamaleaver.net/research/the-ends-of-identity/.
} 
If the individual is not the source of action and choice but the product of systems and connections, this suggests that newness, innovation and the growth of knowledge need to be looked for in the actions and interactions of groups, not only in the motivations, talents and achievements of individuals. Naturally, talented, specialist, expert individuals are vital to the production of 'newness', but it's the system that decides on value: you get the Nobel Prize because the group recognises the merit of your work, not for your merit as such (as many non-winners will attest!).

Here is where the new concept of 'knowledge clubs' comes in; where knowledge is 'non-rivalrous' but 'excludable'. People form clubs for a purpose. Some clubs are organised for the purpose of growing knowledge and ideas. They retain the characteristics of culture: common language, adversarial competitiveness with external clubs, producing not just neutral or inert information but culture-made asymmetries of trust (with various tests and punishments to ensure group coherence), and reluctance to share 'our' knowledge with 'them'. They are also apt to resort to a discursive version of the traditional solution to the problem of how to scale up and consolidate knowledge across multiple demes or groups - namely, conquest and the forcible assimilation of other groups' demic knowledge. The same model can be observed in corporate take-overs; and even in the take-over of academic disciplines from the arts/humanities to the sciences - as has happened successively to economics, psychology, geography ... but not, yet, to culture.

But now global connectivity and the potential for species-wide social networks offers new possibilities for group-formation based on affinity as well as adversarial opposition. Here, we think a powerful explanatory concept is the other term from the economics of goods that has not yet been taken up, that of the knowledge commons (Ostrom; Ostrom \& Hess), and more recently the idea of an 'innovation commons' (Potts 2012). We think that the drive towards Open Access and 'public intellectuals' alike needs to be augmented by urgent attention to how knowledge clubs and commons form and interact. With that will come a new perspective on the intellectual. Our guess is that such a figure will turn out to be a group, or rather a cluster of interacting groups, part human and part technological-media network. We don't think it will be an oppositional figure. It might be entrepreneurial. It might play a regulatory role in system self-correction processes. 'Public thought' is in experimental 
development in many different group-enterprises, from research groups and advocacy/activist groups to firms (large and small) and systems (small-world networks and planetary social networks).

The task at hand is not to pine for the individualism of the intellectual, Parisian or public, nor to fall for opposition as the purpose of the knowledge agent, but to identify where and how new ideas are propagated, and what mechanisms are in place to encourage the development of a 'club' and 'commons' approach to knowledge, one that encourages the formation of new knowledge clubs while sharing knowledge gains. We need also to identify the 'critical' functions of self-organisation, selfregulation and self-correction in groups, looking to system-automation (autopoiesis) for the organisational principle that Negri assigned to the command-and-control Party. Public intellectuals have not proven effective agents for these functions. Meanwhile the scientific, publicity and political 'spheres' have drifted further apart, mutually repelled by low-trust adversarial out-group hostility. Instead of reproducing such oppositions unwittingly, the intellectual function of large-scale social networks needs to get clubby.

\section{References}

Barthes, R. (1977a) Image-Music-Text. London: Fontana.

Barthes, R. (1977b) 'Lecture in inauguration of the Chair of Literary Semiology'. Paris: Collège de France, January 7. Trans. R. Howard. Accessible at: www.albany.edu/ rn774/fall96/barthes.html. [Published in French as Leçon. Paris: Editions du Seuil, 1978.]

Barthes, R. (2005) The Neutral: Lecture Course at the Collège de France 1977-78. New York: Columbia University Press.

Buchanan, J. (1965) 'An Economic Theory of Clubs'. Economica NS, 32(125), 1-14.

Gramsci, A. (1971) Selections from the Prison Notebooks. London: Lawrence and Wishart.

Ford, H. (2013) 'Two or Three Things I Know About Her'. Senses of Cinema, 66.

Online: http://sensesofcinema.com/2013/cteq/two-or-three-things-i-know-abouther/.

Foucault, F. (1977) 'The political function of the intellectual', trans. C. Gordon. Radical Philosophy, 17, 12-14. Fr. original: (1976), 'La fonction politique de 
l'intellectuel'. In D. Defert and F. Ewald (eds) (2001) Dits et écrits II, 19761988, Paris: Gallimard, 109-114.

Gitlin, T. (1987) The Sixties: Years Of Hope, Days Of Rage. New York: Bantam Books.

Harari, Y.N. (2014) Sapiens: A brief history of humankind. London: Harvill Secker. Hartley, J. (2010) 'Paradigm shifters: Tricksters and cultural science'. Cultural Science Journal 3(1), 1-19. Online: http://culturalscience.org/journal/index.php/culturalscience/article/view/30/110.

Hartley J. (2012) Digital Futures for Cultural and Media Studies. Malden MA \& Oxford: Wiley-Blackwell.

Hartley, J., J. Burgess and A. Bruns (eds) (2013) A Companion to New Media Dynamics. Malden MA and Oxford: Wiley-Blackwell.

Hartley, J. and J. Potts (2014) Cultural Science: A Natural History of Stories, Demes, Knowledge and Innovation. London: Bloomsbury.

Jenkins, H., S. Ford and J. Green (2013) Spreadable Media: Creating Value and Meaning in a Networked Culture. New York: NYU Press.

Lucy N. (2016) A Dictionary of Postmodernism. Oxford: Wiley-Blackwell.

Murphy, T. (2005) ‘Editor’s Introduction: Books for Burning'. In Negri (2005), ixxxviii.

Negri, A. (2005) Books for Burning: Between Civil War and Democracy in 1970s Italy. Ed. T. Murphy. London: Verso.

Ostrom, E. (1990) Governing the Commons: The Evolution of Institutions for Collective Action. Cambridge: Cambridge University Press.

Ostrom, E. and C. Hess (2007) 'A framework for analyzing the knowledge commons'. In C. Hess and E. Ostrom (eds) Understanding Knowledge as Common. Cambridge MA: MIT Press, 41-79.

Pagel, M. (2012) Wired for Culture: The Natural History of Human Cooperation. London: Allen Lane.

Potts, J. (2012) 'Innovation in the Commons'. International Schumpeter Society: www.aomevents.com/media/files/ISS\%202012/Potts.pdf.

Sandry, E. (2015) Robots and Communication. UK: Palgrave Pivot. 